\title{
Characteristic of the chemical composition of Artemisia pontica L.
}

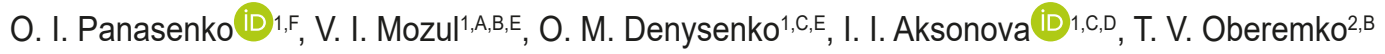

'Zaporizhzhia State Medical University, Ukraine, ${ }^{2}$ LLC "PMD-UKRAINE”, Kyiv

A - research concept and design; B - collection and/or assembly of data; C - data analysis and interpretation; D - writing the article;

$\mathrm{E}$ - critical revision of the article; $\mathrm{F}$ - final approval of the article

The aim of this work is to determine the qualitative and quantitative characteristics of biologically active compounds of Artemisia pontica $\mathrm{L}$. Definition prospects of medicinal herbal raw materials in the treatment of diseases.

Materials and methods. Research material (Artemisia pontica L. herb) was collected in August 2019 in the Zaporizhzhia region, Ukraine. The tincture was obtained by maceration. So, the tincture was being extracted with methyl alcohol at room temperature for 10 days. The tincture was extracted with methyl alcohol at room temperature for 10 days according to the method of preparing tinctures. The study of the chemical composition of tincture of Artemisia pontica L. was carried out using gas chromatograph Agilent 7890B GC System (Agilent, Santa Clara, CA, USA) with mass spectrometric detector Agilent 5977 BGC/MSD (Agilent, Santa Clara, CA, USA) and chromatographic column DB-5ms $(30 \mathrm{~m} \times 250 \mathrm{mkm} \times 0.25 \mathrm{mkm})$.

Results. 26 compounds were identified by analysis. Compounds such as n-hexadecanoic acid (16.71 \%), 9,12,15-(Z,Z,Z)-octadecatrienoic acid (13.29\%), 2-(4a,8-dimethyl-7-oxo-1,2,3,4,4a,7-hexahydronaphthalen-2-yl)-propionic acid (8.80\%), 8-nitro-(1H)quinolin-4-ol-2-one $(6.45 \%)$ and neophytadiene (4.66 \%) prevail in tincture. A literature review showed that $n$-hexadecanoic acid stimulates anti-inflammatory processes in human immune cells through TLR4 receptors, it has antitumor and antidiabetic activity and it also has anti-inflammatory effects. Derivatives of 9,12,15-(Z,Z,Z)-octadecatrienoic acid are used in diabetes therapy. 2-(4a,8-Dimethyl-7-oxo-1,2,3,4,4a,7hexahydronaphthalen-2-yl)-propionic acid is an immunosuppressant and probably improves tissue insulin sensitivity. In addition, it is necessary to underline the presence of neophytadiene that has an anti-inflammatory effect. The presence of $\beta$-phellandrene provides insecticidal and eucalyptol anti-inflammatory effects.

Conclusions. Considering the individual actions of the individual components, Artemisia pontica L. herb can be recommended for further research on its anti-inflammatory, antidiabetic, and antitumor effects.

Key words: Artemisia pontica, chromato-mass spectroscopy, component composition, quantitative content.

Current issues in pharmacy and medicine: science and practice 2021; 14 (1), 23-28

\section{Характеристика хімічного складу Artemisia pontica L.}

\section{О. І. Панасенко, В. І. Мозуль, О. М. Денисенко, І. І. Аксьонова, Т. В. Оберемко}

Мета роботи - встановлення якісних і кількісних характеристик біологічно активних сполук Artemisia pontica L.; визначення перспектив використання лікарської рослинної сировини для лікування захворювань.

Матеріали та методи. Матеріал для дослідження (Artemisia pontica L. трава) зібраний у серпні 2019 р. у Запорізькій області. Настойку одержували методом мацерації. Сировину екстрагували метиловим спиртом за кімнатної температури протягом 10 днів за способом приготування настойок. Хімічний склад настойки Artemisia pontica L. вивчали за допомогою газового хроматографа Agilent 7890B GC System (Agilent, Санта-Клара, Каліфрорнія, США) з мас-спектрометричним детектором Agilent 5977 BGC/MSD (Agilent, Santa Clara, CA, CША) та хроматографрічної колонки DB-5ms (30 м × 250 мкм × 0,25 мкм).

Результати. Під час аналізу встановили 26 сполук. У настойці переважали такі сполуки, як н-гексадеканова кислота (16,71 \%), 9,12,15-(Z,Z,Z)-октадекатрієнова кислота (13,29 \%), 2-(4а,8-диметил-7-оксо-1,2,3,4,4а,7-гексагідронафтален-2-іл)-пропіонова кислота (8,80 \%), 8-нітро-(1Н) хінолін-4-ол-2-он (6,45 \%) та неофітадієн (4,66 \%). Огляд фрахової літератури показав, що н-гексадеканова кислота стимулює протизапальні процеси в імунних клітинах людини через рецептори TLR4, має протипухлинну, протидіабетичну та протизапальну дії.

Похідні 9,12,15-(Z,Z,Z)-октадекатрієнової кислоти використовують у терапії діабету. 2-(4а,8-диметил-7-оксо-1,2,3,4,4а,7-гексагідронафртален-2-іл)-пропіонова кислота є імунодепресантом і, ймовірно, поліпшує чутливість тканин до інсуліну. Необхідно підкреслити наявність неофітадієну, який має протизапальну дію. Наявність $\beta$-фелландрену та евкаліптолу забезпечує інсектицидну та протизапальну дії відповідно.

ARTICLE

INFO

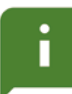

http:l/pharmed.

zsmu.edu.ualarticlel view/226743
UDC 615.322:582.998.16-119.2

DOI: $10.14739 / 2409-2932.2021 .1 .226743$

Current issues in pharmacy and medicine: science and practice $2021 ; 14$ (1), 23-28

Key words: Artemisia pontica, chromato-mass spectroscopy, component composition, quantitative content.

*E-mail: bruttik2@gmail.com

Received: 05.11.2020 // Revised: 17.11.2020 // Accepted: 23.11.2020 
Висновки. Враховуючи індивідуальні дії окремих компонентів, Artemisia pontica L. траву можна рекомендувати для наступних досліджень щодо її протизапальної, протидіабетичної та протипухлинної дії.

Ключові слова: Artemisia pontica, хромато-мас-спектроскопія, компонентний склад, кількісний вміст.

Актуальні питання фрармацевтичної і медичної науки та практики. 2021. Т. 14, № 1(35). С. $23-28$

\section{Характеристика химического состава Artemisia pontica L.}

\section{А. И. Панасенко, В. И. Мозуль, О. Н. Денисенко, И. И. Аксёнова, Т. В. Оберемко}

Цель работы - определение качественных и количественных характеристик биологически активных соединений Artemisia pontica L.; определение перспектив использования лекарственного растительного сырья для лечения заболеваний.

Материалы и методы. Материал для исследования (трава Artemisia pontica L.) собран в августе 2019 г. в Запорожской области, Украина. Настойку получали путем мацерации. Сырье экстрагировали метиловым спиртом при комнатной температуре в течение 10 дней согласно методу приготовления настоек. Химический состав настойки Artemisia pontica L. изучали с помощью газового хроматограффa Agilent 7890B GC System (Agilent, Санта-Клара, Калифорния, США) с масс-спектрометрическим детектором Agilent 5977 BGC/MSD (Agilent, Santa Clara, CA, США) и хроматографической колонки DB-5ms (30 м × 250 мкм × 0,25 мкм).

Результаты. В ходе анализа установлены 26 соединений. В настойке преобладали такие соединения, как н-гексадекановая кислота (16,71%), 9,12,15-(Z,Z,Z)-октадекатриеновая кислота (13,29%), 2(4а,8-диметил-7-оксо-1,2, 3,4,4а,7-гексагидронафтален-2-ил)-пропионовая кислота $(8,80 \%), 8$-нитро(1Н)-хинолин-4-ол-2-он $(6,45 \%)$ и неофитадиен $(4,66 \%)$. Обзор научной литературы показал, что н-гексадекановая кислота стимулирует противовоспалительные процессы в иммунных клетках человека через рецепторы TLR4, обладает противоопухолевым, противодиабетическим и противовоспалительным действиями. Производные 9,12,15-(Z, Z, Z)-октадекатриеновой кислоты используют в терапии диабета. 2(4а,8-диметил-7-оксо-1,2,3,4,4а,7-гексагидронафтален-2-ил)-пропионовая кислота - иммунодепрессант, вероятно, улучшает чувствительность тканей к инсулину. Следует отметить наличие неофитадиена, который обладает противовоспалительным действием. Наличие $\beta$-фелландрена и евкалиптола обеспечивает инсектицидное и противовоспалительное действие соответственно.

Выводы. Учитывая индивидуальные действия каждого компонента, Artemisia pontica L. траву можно рекомендовать для дальнейших исследований на противовоспалительное, противодиабетическое и противоопухолевое действия.

Ключевые слова: Artemisia pontica, хромато-масс-спектроскопия, компонентный состав, количественное содержание.

Актуальные вопросы фрармацевтической и медицинской науки и практики. 2021. Т. 14, № 1(35). С. 23-28

The genus Artemisia L. includes more than 400 species that belong to the Asteraceae family. Artemisia pontica L. is a shrub with a height of $40-100 \mathrm{~cm}$ with a creeping rhizome and a lignified stem in the lower part, densely leafy from the middle and above [1].

This is an ornamental plant. It is distributed mainly in the southern part of Central and Eastern Europe. In Ukraine, Artemisia pontica L. is found in Mykolaiv, Odesa, and Zaporizhzhia regions. It grows in dry meadows, clearings, forest edges, and the steppes [2].

It is used in medicine as an antiseptic for the oral cavity (Maraslavin, Bulgaria). Research data revealed the presence of anti-inflammatory, analgesic, wound healing, antifungal, and antimicrobial effects $[3,4]$.

Artemisia pontica L. was previously cultivated as a spicy-aromatic plant in Western Europe and North America. Although Artemisia pontica L. is grown as an ornamental plant in gardens, it can also be used as feed for small livestock, horses, and camels [5].

There are evident facts that plants of the genus Artemisia $L$. have anthelmintic, antibacterial, antifungal, repellent, narcotic [6-8], antioxidant [9-11] properties. However, they also have toxic effects $[6,12]$.

Despite the potential perspective of using this plant in medicine, the chemical composition of Artemisia pontica L. populations that grow in Ukraine is not well investigated. Before the research of the chemical composition of the herb Artemisia pontica L. was conducted.

\section{Aim}

To determine the qualitative and quantitative characteristics of biologically active compounds of Artemisia pontica L. Definition prospects of medicinal herbal raw materials in the treatment of diseases.

\section{Materials and methods}

Plant materials. Research material (Artemisia pontica L. herb) was collected in August 2019 in the Zaporizhzhia region. Herbarium samples were deposited at the herbarium of the Faculty of Pharmacy of Zaporizhzhia State Medical University.

Extraction. According to the general method of preparing tinctures, the tincture was obtained by maceration. The tincture was being extracted with methyl alcohol at room temperature for 10 days [13]. Then $0.1 \mathrm{ml}$ of tincture was placed in a $1 \mathrm{ml}$ micro flask and was brought with methanol to $0.5 \mathrm{ml}$.

Equipment. The completeness of the reactions and the individuality of the resulting compounds were controlled by the gas chromatograph Agilent 7890B with a 5977B mass spectrometry detector. The column was DB-5ms $30 \mathrm{~m} \times 250 \mu \mathrm{m} \times 0.25 \mu \mathrm{m}$ with length. The gas-carrier speed (helium) was $1.6 \mathrm{ml} / \mathrm{min}$. Injection volume was 0.5 $\mu 1$. The separation of the flow was 1:50. The temperature of the sampling unit was $230{ }^{\circ} \mathrm{C} \rightarrow 12{ }^{\circ} \mathrm{C} / \mathrm{s} \rightarrow 275^{\circ} \mathrm{C}$. Thermostat temperature: programmable, $240{ }^{\circ} \mathrm{C}$ (1-minute 
delay) $\rightarrow 5^{\circ} \mathrm{C} / \mathrm{min} \rightarrow 280{ }^{\circ} \mathrm{C}$ (1-minute delay). The total time of examination were $10 \mathrm{~min}$. Temperature of interface GS/MS $-280{ }^{\circ} \mathrm{C}$; ion sources $-230{ }^{\circ} \mathrm{C}$; quadrupole mass analyzer $-150^{\circ} \mathrm{C}$. Type of ionization: EI with an electron energy of $70 \mathrm{eV}$. The range of mass numbers that was scanned: $30-500 \mathrm{~m} / \mathrm{z}$.

\section{Results}

It was found that the methanol tincture of Artemisia pontica L. contains 26 different components. Among them, it was identified: 5 fatty acids (41.24\%), terpenoids of different classes - 16 (29.83\%), heterocyclic compounds - 2(7.67\%), alkenes - $1(6.33 \%)$, triterpenes of carboxylic acids $1(1.23 \%)$, cycloalkane alcohol - $1(0.89 \%)$.

Compounds such as N-hexadecanoic acid (16.71\%), 9,12,15-(Z,Z,Z)-octadecatrienoic acid (13.29\%), 2-(4a,8-dimethyl-7-oxo-1,2,3,4,4a,7-hexahydronaphthalen-2-yl)-pro- pionic acid (8.80\%), 8-nitro- $(1 \mathrm{H})$ quinolin-4-ol-2-one $(6.45 \%)$ and neophytadiene $(4.66 \%)$ are quantitatively prevail among the total content of all components.

The results of the study are in Table 1.

Such components as $n$-hexadecanoic acid with a retention time of $16.27 \mathrm{~min}$ and 9,12,15-(Z,Z,Z)-octadecatrienoic acid $(\mathrm{RT}=17.917 \mathrm{~min})$ were identified on chromatogram of the components of Artemisia pontica L. (Fig. 1).

\section{Discussion}

The populations of Artemisia pontica L. that grow on the territory of Ukraine differ significantly from the populations of other countries in chemical composition. The main active ingredients of the Kazakhstan fraction are flavonoids 7-O-methyl-and 4',7-di-O-methyl-esters of apigenin [14], while the Ukrainian fraction is dominated by fatty acids. Regarding the study of the component composition of water extracts of other Arte-

Table 1. Qualitative and quantitative composition of biologically active substances of Artemisia pontica L.

\begin{tabular}{|c|c|c|c|}
\hline & RT, $\min$ & Compound Label & Area Sum \% \\
\hline 1. & 4.125 & $\beta$-phellandrene & 3.69 \\
\hline 2. & 4.914 & Eucalyptol & 3.37 \\
\hline 3. & 5.412 & 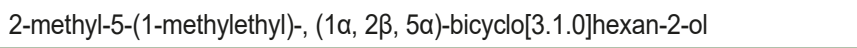 & 0.95 \\
\hline 4. & 5.761 & (1R,4R,5S)-1-isopropyl-4-methoxy-4-methylbicyclo[3.1.0]hexane & 1.37 \\
\hline 5. & 6.879 & endo-borneol & 1.25 \\
\hline 6. & 7.176 & L-a-terpineol & 1.1 \\
\hline 7. & 10.129 & 1-deoxy-inositol & 0.89 \\
\hline 8. & 12.326 & Caryophyllene oxide & 1.22 \\
\hline 9. & 12.596 & Quinic acid & 1.23 \\
\hline 10. & 13.205 & Neointermedeol & 1.82 \\
\hline 11. & 14.011 & Chamazulene & 1.26 \\
\hline 12. & 14.164 & Tetradecanoic acid & 0.92 \\
\hline 13. & 14.903 & 1-heptatriacotanol & 1.71 \\
\hline 14. & 15.006 & Neophytadiene & 4.66 \\
\hline 15. & 15.257 & Phytol, acetate* & 1.21 \\
\hline 16. & 15.449 & Phytol, acetate* & 1.91 \\
\hline 17. & 15.757 & 8-nitro-(1H)quinolin-4-ol-2-one & 6.45 \\
\hline 18. & 16.27 & n-hexadecanoic acid & 16.71 \\
\hline 19. & 17.215 & 4-(3-mercapto-4-methyl-5-(4H-1,2,4-triazolyl))-pyridine & 1.22 \\
\hline 20. & 17.364 & 2-(4a,8-dimethyl-7-oxo-1,2,3,4,4a,7-hexahydronaphthalen-2-yl)-propionic acid & 8.8 \\
\hline 21. & 17.689 & Phytol & 4.4 \\
\hline 22. & 17.917 & 9,12-(Z,Z)-octadecadienoic acid & 1.52 \\
\hline 23. & 17.978 & 9,12,15-(Z,Z,Z)-octadecatrienoic acid & 13.29 \\
\hline 24. & 18.212 & 2,6,10,15,19,23-(all-E)-hexamethyl-1,6,10,14,18,22-tetracosahexaen-3-ol & 2.07 \\
\hline 25. & 18.787 & 1-heptatriacotanol & 2.5 \\
\hline 26. & 22.837 & 17-pentatriacontene & 1.67 \\
\hline
\end{tabular}

*: these compounds are believed to be isomers. 


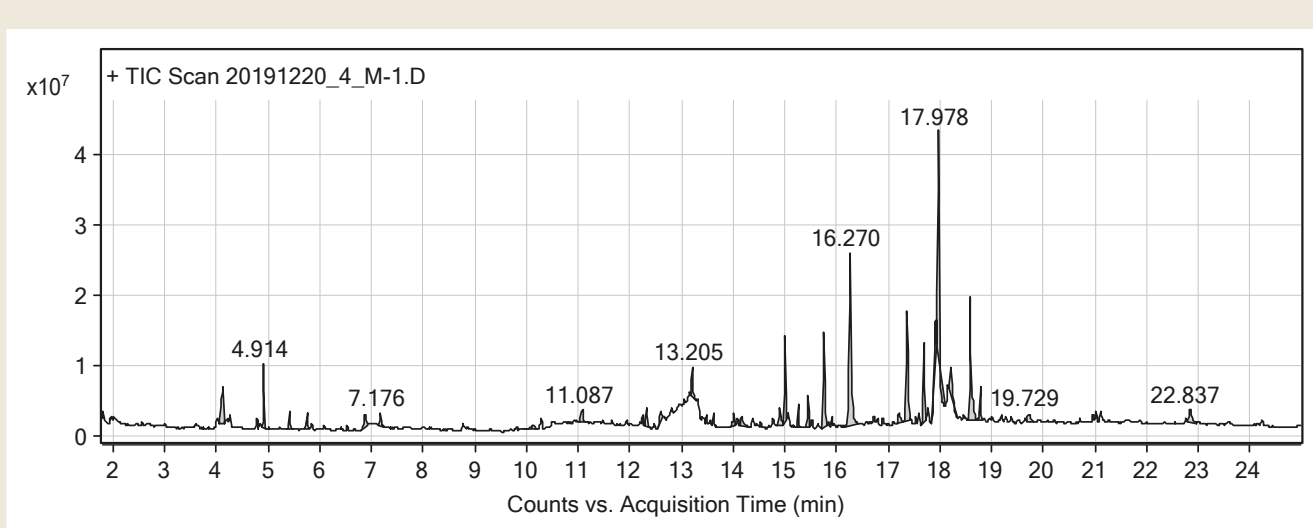

misia L. species, Russian scientists found that laminitol was the dominant component of aqueous extracts of $A$. absinthium L., A. latifolia Ledeb., A. armeniaca Lam. [15].

Considering the terpenoid fraction, the majority of the Ukrainian population are $\beta$-phellandrene and eucalyptol. Cimol and 1,8-cineole prevail in Siberian populations [16]; $\alpha$-thujone [17] dominates in Moroccan population; 1,8-cineole and camphor prevail in Bulgarian population [18].

It should be noted that the terpenoid fraction of Artemisia pontica L. was significantly different in chemical composition from the other representatives of the genus Artemisia L. For example, $A$. absinthium L. had the highest $\beta$-myrcene content, A. austriaca Jacq. had camphor [9], and A. frigida Willd. had 1,8-cineole and camphor, $A$. argyrophylla contained artemisia ketone and artemisia alcohol acetate [19].

The literature review illustrated that $n$-hexadecanoic acid (palmitic acid) was the most common fatty acid in nature, which was a part of the glycerides of most animal fats, vegetable oils, and waxes. It had stimulated anti-inflammatory processes in human immune cells through TLR4 receptors [20], it had antitumor and antidiabetic activity [21] and it also had anti-inflammatory effects [22].

9,12,15-(Z,Z,Z)-octadecatrienoic acid was an isomer of 5,9,12-(Z,Z,Z)-octadecatrienoic acid that was better known as pinolenic acid. It had been established that pinolenic acid can affect immune processes [23], and was a dual FFA1/FFA4 agonist with potential effect against metabolic diseases such as insulin resistance and type 2 diabetes [24].

There was also experimental data on the presence of cholesterol-lowering effect on the LDL receptor activity of human hepatoma HepG2 cells [25]. Investigations of pinolenic acid as an inhibitor of human breast cancer MDA-MB-231 cell metastasis in vitro may be perspective [26].

2-(4a,8-dimethyl-7-oxo-1,2,3,4,4a,7-hexahydronaphthalen-2-yl)-propionic acid was a propionic acid derivative that was known to be lowers fatty acids content in liver and plasma, reduces food intake, exerts immunosuppressive actions and probably improves tissue insulin sensitivity [27].

In addition, it was necessary to underline the presence of neophytadiene that has an anti-inflammatory effect [28].

The presence of $\beta$-phellandrene provides insecticidal [29] and eucalyptol anti-inflammatory effect [30,31].
Considering the given all the above the herb Artemisia pontica L. can be recommended for further studies due to its anti-inflammatory, antidiabetic and antitumor effects.

\section{Conclusions}

1. For the first time the qualitative and quantitative composition of the components of the Artemisia pontica L. herb that grows in Ukraine was established by using a gas chromatogram;

2. It was identified 26 components that belong to different classes of biologically active compounds;

3 . The quantitative content was dominated by n-hexadecanoic acid (16.71 \%), 9,12,15-(Z,Z,Z)-octadecatrienoic acid (13.29\%), 2-(4a,8-dimethyl-7-oxo-1,2,3,4,4a,7-hexahydronaphthalen-2-yl)-propionic acid (8.80\%), 8-nitro-(1H) quinolin-4-ol-2-one (6.45\%), and neophytadiene (4.66\%). Considering their biological effect, the studied raw materials can be recommended for further studies on anti-inflammatory, antidiabetic, and antitumor effects.

Prospects for further research. The herb of Artemisia pontica L. is a source of biologically active substances that have anti-inflammatory, antidiabetic and antitumor effects.

Funding

The research is an integral part of the joint complex work of Department of Pharmacognosy, Pharmacology and Botany of Zaporizhzhia State Medical University.

Conflicts of interest: authors have no conflict of interest to declare. Конфлікт інтересів: відсутній.

Information about authors:

Panasenko O. I., Dr. hab., Professor, Head of the Department of Natural Sciences for Foreign Students and Toxicological Chemistry, Zaporizhzhia State Medical University, Ukraine.

ORCID ID: 0000-0002-6102-3455

Mozul V. I., PhD, Associate Professor of the Department of

Pharmacognosy, Pharmacology and Botany, Zaporizhzhia State Medical University, Ukraine.

Denysenko O. M., PhD, Associate Professor of the Department of Pharmacognosy, Pharmacology and Botany, Zaporizhzhia State Medical University, Ukraine. 
Aksonova I. I., PhD, Teaching Assistant of the Department of Pharmacognosy, Pharmacology and Botany, Zaporizhzhia State Medical University, Ukraine.

ORCID ID: 0000-0002-3534-700X

Oberemko T. V., Director of LLC "PMD-UKRAINE", Kyiv.

\section{Відомості про авторів:}

Панасенко О. І., д-р фрарм. наук, професор, зав. каф. природничих дисциплін для іноземних студентів та токсикологічної хімії, Запорізький державний медичний університет, Україна. Мозуль В. І., канд. фрарм. наук, доцент каф. фрармакогнозії, фармакології та ботаніки, Запорізький державний медичний університет, Україна.

Денисенко О. М., канд. фарм. наук, доцент каф. фармакогнозії, фармакології та ботаніки, Запорізький державний медичний університет, Україна.

Аксьонова І. І., канд. фарм. наук, асистент каф. фармакогнозії, фармакології та ботаніки, Запорізький державний медичний університет, Україна.

Оберемко Т. В., директор ТОВ «ФМД-Україна», м. Київ.

\section{Сведения об авторах:}

Панасенко А. И., д-р фарм. наук, профессор, зав. каф. естественных дисциплин для иностранных студентов и токсикологической химии, Запорожский государственный медицинский университет, Украина. Мозуль В. И., канд. фарм. наук, доцент каф. фрармакогнозии, фармакологии и ботаники, Запорожский государственный медицинский университет, Украина.

Денисенко О. Н., канд. фрарм. наук, доцент каф. фрармакогнозии, фармакологии и ботаники, Запорожский государственный медицинский университет, Украина.

Аксёнова И. И., канд. фарм. наук, ассистент каф. фрармакогнозии, фармакологии и ботаники, Запорожский государственный медицинский университет, Украина.

Оберемко Т. В., директор ТОВ «ФМД-Украина», г. Киев.

\section{References}

[1] Artemisia pontica L. (n.d.). The Plant List. http://www.theplantlist.org/ tpl1.1/record/gcc-3675

[2] Komarov, V. L., Shishkina, B. K., \& Bobrova, E. G. (Eds.). (1961). Flora SSSR [Flora of the USSR] (Vol. 26). Izd. Akad. Nauk SSSR. [in Russian].

[3] Maraslavin®. (n.d.). Kompendium - likarski preparaty. https://compendium.com.ua/info/154085/maraslavin-sup-sup-/

[4] Savchenko, L. N., Marinina, T. F., \& Lukashuk, S. P. (2012). Sovremennye podkhody $\mathrm{k}$ lecheniyu i profilaktiki zabolevanii parodonta [Modern approaches to the treatment and prevention of periodontal disease]. Izvestia of Samara Scientific Center of the Russian Academy of Sciences, 14(5), 758-760. [in Russian].

[5] Chopik, V. I., Dudchenko, L. G., \& Krasnova, A. N. (1983). Dikorastushchie poleznye rasteniya Ukrainy [Wild useful plants of Ukraine]. Kiev: Naukova dumka. [in Russian].

[6] Rezaeinodehi, A., \& Khangholi, S. (2008). Chemical composition of the essential oil of Artemisia absinthium growing wild in Iran. Pakistan journal of biological sciences : PJBS, 11(6), 946-949. https://doi. org/10.3923/pjbs.2008.946.949

[7] Dhen, N., Majdoub, O., Souguir S., Tayeb, W., Laarif A., \& Chaieb, I. (2014). Chemical composition and fumigant toxicity of Artemisia absinthium essential oil against Rhyzopertha dominica and Spodoptera littoralis. Tunisian Journal of Plant Protection, 9(1), 57-65.

[8] Khangholil, S., \& Rezaeinodehi, A. (2008). Effect of drying temperature on essential oil content and composition of sweet wormwood (Artemisia annua) growing wild in Iran. Pakistan journal of biological sciences : PJBS, 11(6), 934-937. https://doi.org/10.3923/pjbs.2008.934.937

[9] Altunkaya, A., Yıldırım, B., Ekici, K., \& Terzioğlu, Ö. (2014). Determining essential oil composition, antibacterial and antioxidant activity of water wormwood extracts. GIDA, 39(1), 17-24.

[10] Riahi, L., Chograni, H., Elferchichi, M., Zaouali, Y., Zoghlami, N., \& Mliki, A. (2013). Variations in Tunisian wormwood essential oil profiles and phenolic contents between leaves and flowers and their effects on antioxidant activities. Industrial Crops and Products, 46, 290-296. https://doi.org/10.1016/j.indcrop.2013.01.036
[11] Msaada, K., Salem, N., Bachrouch, O., Bousselmi, S., Tammar, S., Alfaify, A., Sane, K. A., Ammar, W. B., Azeiz, S., Brahim, A. H., Hammami, M., Selmi, S., Limam, F., \& Marzouk, B. (2015). Chemical Composition and Antioxidant and Antimicrobial Activities of Wormwood (Artemisia absinthium L.) Essential Oils and Phenolics. Journal of Chemistry, 2015, Article ID 804658. https://doi.org/10.1155/2015/804658

[12] Judzentiene, A., Budiene, J., Gircyte, R., Masotti, V., \& Laffont-Schwob, I. (2012). Toxic Activity and Chemical Composition of Lithuanian Wormwood (Artemisia absinthium L.) Essential Oils. Records of Natural Products, 6(2), 180-183

[13] Ministry of Health of Ukraine. (1993, September 7). Pro zatverdzhennia Instruktsii po pryhotuvanniu v aptekakh likarskykh form z ridkym dyspersiinym seredovyshchem [About the statement of the Instruction on preparation in drugstores of dosage forms with the liquid dispersion environment (No. 197)]. https://zakon.rada.gov.ua/rada/show/ v0197282-93\#Text

[14] Talzhanov, N. A., Sadyrbekov, D. T., Smagulova, F. M., Tkachev, A. V., Atazhanova, G. A., Tuleuov, B. I., \& Adekenov, S. M. (2005). Components of Artemisia pontica. Chemistry of Natural Compounds, 41, 178-181.

[15] Rzhevskii, S. G., Potapov, M. A., Shikhaliev, Kh. S., \& Fedulova, T. P. (2019). Analiz komponentnogo sostava vodnykh ekstraktov Artemisia absinthium L., Artemisia armeniaca Lam., i Artemisia latifolia Ledeb. [Analysis of the component composition of aquatic extracts Artemisia absinthium L., Artemisia armeniaca Lam., and Artemisia latifolia Ledeb.]. Khimiya rastitel'nogo syr'ya, (4), 285-292. [in Russian]. https://doi.org/10.14258/jcprm.2019045149

[16] Khanina, M. A., Serykh, E. A., Korolyuk, A. Yu., Bel'chenko, L. A., Pokrovskii, L. M., \& Tkachev, A. V. (2000). Sostav efirnogo masla sibirskikh populyatsii Artemisia pontica L. - perspektivnogo lekarstvennogo rasteniya [Essential oil composition of siberian populations Artemisia pontica L.]. Khimiya rastitel'nogo syr'ya, (3), 85-94. [in Russian].

[17] Derwich E., Benziane Z., Boukir A. (2009). Chemical compositions and insectisidal activity of essential oils of three plants Artemisia SP: Artemisia herba-alba, Artemisia absinthium and Artemisia Pontica (Morocco). Electronic Journal of Environmental, Agricultural and Food Chemistry, 8(11), 1202-1211.

[18] Bos, R., Stojanova, A. St., Woerdenbag, H. J., Koulman, A., \& Quax, W. J. (2005). Volatile components of the aerial parts of Artemisia pontica L. grown in Bulgaria. Flavour and Fragrance Journal, 20(2), 145-148. https://doi.org/10.1002/ffj.1399

[19] Korolyuk, E. A., \& Tkachev, A. V. (2010). Chemical Composition of the Essential Oil from Two Wormwood Species Artemisia frigida and Artemisia argyrophylla. Russian Journal of Bioorganic Chemistry, 2010, 36(7), 884-893. https://doi.org/10.1134/S1068162010070162

[20] Nicholas, D. A., Zhang, K., Hung, C., Glasgow, S., Aruni, A. W., Unternaehrer, J., Payne, K. J., Langridge, W., \& De Leon, M. (2017). Palmitic acid is a toll-like receptor 4 ligand that induces human dendritic cell secretion of IL-1ß. PloS one, 12(5), e0176793. https://doi. org/10.1371/journal.pone.0176793

[21] Thirunavukkarasu, K., Rajkumar, P., Selvaraj, S., \& Kumaresan, S. (2016). GC-MS analysis of Gymnema sylvestre leaves methanolic extract for antidiabetic and anticancer drug identification. Journal of Chemical and Pharmaceutical Sciences, 9(2), 1011-1013.

[22] Aparna, V., Dileep, K. V., Mandal, P. K., Karthe, P., Sadasivan, C., \& Haridas, M. (2012). Anti-inflammatory property of $n$-hexadecanoic acid: structural evidence and kinetic assessment. Chemical biology \& drug design, 80(3), 434-439. https://doi.org/10.1111/j.17470285.2012.01418.x

[23] Matsuo, N., Osada, K., Kodama, T., Lim, B. O., Nakao, A., Yamada, K., \& Sugano, M. (1996). Effects of gamma-linolenic acid and its positional isomer pinolenic acid on immune parameters of brown-Norway rats. Prostaglandins, leukotrienes, and essential fatty acids, 55(4), 223-229. https://doi.org/10.1016/s0952-3278(96)90002-2

[24] Christiansen, E., Watterson, K. R., Stocker, C. J., Sokol, E., Jenkins, L., Simon, K., Grundmann, M., Petersen, R. K., Wargent, E. T., Hudson, B. D., Kostenis, E., Ejsing, C. S., Cawthorne, M. A., Milligan, G., \& Ulven, T. (2015). Activity of dietary fatty acids on FFA1 and FFA4 and characterisation of pinolenic acid as a dual FFA1/FFA4 agonist with potential effect against metabolic diseases. The British journal of nutrition, 113(11), 1677-1688. https://doi.org/10.1017/S000711451500118X

[25] Lee, J. W., Lee, K. W., Lee, S. W., Kim, I. H., \& Rhee, C. (2004). Selective increase in pinolenic acid (all-cis-5,9,12-18:3) in Korean pine nut oil by crystallization and its effect on LDL-receptor activity. Lipids, 39(4), 383-387. https://doi.org/10.1007/s11745-004-1242-2 
[26] Chen, S. J., Hsu, C. P., Li, C. W., Lu, J. H., \& Chuang, L. T. (2011). Pinolenic acid inhibits human breast cancer MDA-MB-231 cell metastasis in vitro. Food chemistry, 126(4), 1708-1715. https://doi. org/10.1016/.foodchem.2010.12.064

[27] Al-Lahham, S. H., Peppelenbosch, M. P., Roelofsen, H., Vonk, R. J., \& Venema, K. (2010). Biological effects of propionic acid in humans; metabolism, potential applications and underlying mechanisms. Biochimica et biophysica acta, 1801(11), 1175-1183. https://doi. org/10.1016/i.bbalip.2010.07.007

[28] Bhardwaj, M., Sali, V. K., Mani, S., \& Vasanthi, H. R. (2020). Neophytadiene from Turbinaria ornata Suppresses LPS-Induced Inflammatory Response in RAW 264.7 Macrophages and Sprague Dawley Rats. Inflammation, 43(3), 937-950. https://doi.org/10.1007/ s10753-020-01179-z

[29] Cheng, Z., Jiang, J., Yang, X., Chu, H., Jin, M., Li, Y., Tao, X., Wang, S., Huang, Y., Shang, L., Wu, S., Hao, W., \& Wei, X. (2017). The research of genetic toxicity of $\beta$-phellandrene. Environmental toxicology and pharmacology, 54, 28-33. https://doi.org/10.1016/i.etap.2017.06.011

[30] Juergens, U. R., Dethlefsen, U., Steinkamp, G., Gillissen, A., Repges, R., \& Vetter, H. (2003). Anti-inflammatory activity of 1.8-cineol (eucalyptol) in bronchial asthma: a double-blind placebo-controlled trial. Respiratory medicine, 97(3), 250-256. https://doi.org/10.1053/ rmed.2003.1432

[31] Juergens, U. R., Engelen, T., Racké, K., Stöber, M., Gillissen, A., \& Vetter, H. (2004). Inhibitory activity of 1,8-cineol (eucalyptol) on cytokine production in cultured human lymphocytes and monocytes. Pulmonary pharmacology \& therapeutics, 17(5), 281-287. https://doi. org/10.1016/j.pupt.2004.06.002 